\title{
Beyond the neonate: how do anesthetics affect the fetal brain?
}

\section{Hyungseok Seo and Jae-Woo Yi}

\author{
Department of Anesthesiology and Pain Medicine, Kyung Hee University Hospital at Gangdong, Kyung Hee \\ University College of Medicine, Seoul, Korea
}

The neurotoxic effect of anesthetics on the developing brain is a long-standing clinical issue. Numerous animal and human studies have demonstrated the neurotoxicity of anesthetics on the developing brain [1-4]. In the present issue of the Korean Journal of Anesthesiology (KJA), we discuss the influence of age and sex on the long-term behavioral consequences of multiple exposures during the fetal period. In the present issue of $K J A$, Chung et al. [5] showed that multiple sevoflurane exposure during the second trimester of pregnancy can affect learning and memory function in young mice, especially in female mice.

The general anesthesia compared to spinal anesthesia (GAS) study [6], a recent international multicenter, randomized controlled trial, demonstrated no evidence of the increased risk of an adverse neurodevelopmental effect of a short period of sevoflurane anesthesia in 2-year-old children. However, we still cannot rule out the possibility of certain harmful effects of anesthesia on the developing brain. Accordingly, the U.S. Food and Drug Administration (FDA) issued a warning that the repeated or lengthy use of anesthesia in children less than 3 years of age or during the third trimester of pregnancy may affect the child's brain development (https://www.fda.gov/Drugs/DrugSafety/ ucm532356.htm). They also updated their warnings to state that these drugs may negatively affect brain development in children less than 3 years of age (https://www.fda.gov/Drugs/DrugSafety/ ucm554634.htm). Moreover, Strategies for Mitigation of Anesthesia-Related Neurotoxicity in Tots (SmartTots), established by the FDA and the International Anesthesia Research Society, continues to update its regulations on the safe use of anesthetics and sedatives in children, based on the most recent knowledge (http://smarttots.org/).

Given the lack of clinical and experimental evidence, apart from the putative negative effects on children, it is difficult to determine whether anesthetics may affect neurodevelopment of the fetal brain. Many factors, including microbial composition, immune activation, metabolism, and neural pathways, can cause neurodevelopmental disabilities [7]. Among these, age, the number of exposures, and sex were regarded as the most influential factors. Thus, current animal studies tend to focus on the age of exposure [8-10]. Lee et al. [11] also previously revealed that neither single nor multiple exposures to sevoflurane during fetal development affected long-term behavioral dysfunction. In their article in the present issue, Chung et al. [5] reported an interesting finding that sevoflurane exposure only affected the learning and memory functions in female mice. This finding suggests differences between the sexes at physiological and molecular levels, which may warrant further detailed experimental studies.

\section{ORCID}

Hyungseok Seo, https://orcid.org/0000-0003-4574-9122

Jae-Woo Yi, https://orcid.org/0000-0001-6474-5624

Corresponding author: Jae-Woo Yi, M.D., Ph.D.

Department of Anesthesiology and Pain Medicine, Kyung Hee University Hospital at Gangdong, Kyung Hee University College of Medicine, 892, Dongnam-ro, Gangdong-gu, Seoul 05278, Korea

Tel: 82-2-440-6192, Fax: 82-2-440-7808

Email: mdyjwchk@khu.ac.kr

ORCID: https://orcid.org/0000-0001-6474-5624

Korean J Anesthesiol 2017 December 70(6): 589-590

https://doi.org/10.4097/kjae.2017.70.6.589

(c) This is an open-access article distributed under the terms of the Creative Commons Attribution Non-Commercial License (http://creativecommons.org/ licenses/by-nc/4.0/), which permits unrestricted non-commercial use, distribution, and reproduction in any medium, provided the original work is properly cited. 


\section{References}

1. Stratmann G. Review article: Neurotoxicity of anesthetic drugs in the developing brain. Anesth Analg 2011; 113: 1170-9.

2. Jevtovic-Todorovic V, Hartman RE, Izumi Y, Benshoff ND, Dikranian K, Zorumski CF, et al. Early exposure to common anesthetic agents causes widespread neurodegeneration in the developing rat brain and persistent learning deficits. J Neurosci 2003; 23 : 876-82.

3. Rizzi S, Ori C, Jevtovic-Todorovic V. Timing versus duration: determinants of anesthesia-induced developmental apoptosis in the young mammalian brain. Ann N Y Acad Sci 2010; 1199: 43-51.

4. Gleich S, Nemergut M, Flick R. Anesthetic-related neurotoxicity in young children: an update. Curr Opin Anaesthesiol 2013; $26: 340-7$.

5. Chung W, Yoon S, Shin YS. Multiple exposures of sevoflurane during pregnancy induces memory impairment in young female offspring mice. Korean J Anesthesiol 2017; 70: 642-7.

6. Davidson AJ, Disma N, de Graaff JC, Withington DE, Dorris L, Bell G, et al. Neurodevelopmental outcome at 2 years of age after general anaesthesia and awake-regional anaesthesia in infancy (GAS): an international multicentre, randomised controlled trial. Lancet 2016; 387: 239-50.

7. Borre YE, O'Keeffe GW, Clarke G, Stanton C, Dinan TG, Cryan JF. Microbiota and neurodevelopmental windows: implications for brain disorders. Trends Mol Med 2014; 20: 509-18.

8. Suehara T, Morishita J, Ueki M, Ueno M, Maekawa N, Mizobuchi S. Effects of sevoflurane exposure during late pregnancy on brain development of offspring mice. Paediatr Anaesth 2016; 26: 52-9.

9. Kong FJ, Tang YW, Lou AF, Chen H, Xu LH, Zhang XM, et al. Effects of isoflurane exposure during pregnancy on postnatal memory and learning in offspring rats. Mol Biol Rep 2012; 39: 4849-55.

10. Luo F, Hu Y, Zhao W, Zuo Z, Yu Q, Liu Z, et al. Maternal exposure of rats to isoflurane during late pregnancy impairs spatial learning and memory in the offspring by up-regulating the expression of histone deacetylase 2. PLoS One 2016; 11: e0160826.

11. Lee S, Chung W, Park H, Park H, Yoon S, Park S, et al. Single and multiple sevoflurane exposures during pregnancy and offspring behavior in mice. Paediatr Anaesth 2017; 27: 742-51. 